\title{
Beş yaş altında malnütrisyon tanısı ile üçüncü basamak bir merkezde yatırılarak izlenen olguların değerlendirilmesi
}

\author{
Evaluation of cases under five years old hospitalized with malnutrition in a tertiary care \\ center
}

Dilek Kaçar, Emine Polat, Pelin Zorlu

Gönderilme tarihi:22.10.2021

Kabul tarihi:19.11.2021

\section{Öz}

Amaç: Besin eksikliği sonucunda normal büyümenin duraklaması şeklinde bulgu veren malnütrisyon, en sık erken çocukluk döneminde görülür. Malnütrisyona komplikasyonların eşlik ettiği ağır olgular hastanede tedavi edilmelidir. Bu çalışmada, malnütrisyon tanısı ile hastanede yatırılarak izlenen beş yaş altındaki çocukların izlemlerinin değerlendirilmesi amaçlanmıştır.

Gereç ve yöntem: Çalışmada; düzeltilmiş yaşları 1-60 ay arasında değişen, üçüncü basamak bir eğitim ve araştırma hastanesinde malnütrisyon tanısı ile Mayıs 2006-Mayıs 2011 tarihleri arasında yatırılarak takip ve tedavi edilen hastalar retrospektif olarak değerlendirilmiştir. Hastaların beslenme durumları 2006 Dünya Sağlık Örgütü büyüme standartlarına göre hesaplanan z skorları ile belirlenmiştir.

Bulgular: Çalışmaya alınan 97 hastanın tamamının yaşa göre ağırlık z skoru -3'ün altında olup çok düşük kilolulardı. Grupta, düşük doğum ağırlığı (grupta \%23,7, toplumda \%10-11) ve anne baba akrabalığı (grupta $\% 48,7$, toplumda \%21-22) toplumdan daha yüksek orandaydı. Daha önce hastanede yatış (\%54,6), prematürite $(\% 15,5)$, kronik hastalık oranları $(\% 18,5)$ da yüksekti ve hastaların önemli bir kısmı $(\% 15,4)$ çalışma süresindeki yatışlarında ek hastalık tanısı almıştı. Mortalite oranı \%5,1'di ve kronik malnütrisyonun daha ağır olduğu 6 ay altındaki çocuklarda gelişmişti.

Sonuç: Malnütrisyon sebebi ile hastanede yatırılarak izlenen beş yaş altındaki çocukların sıklıkla altta yatan tıbbi durumları bulunmaktadır. Hastaların sosyal ve ekonomik koşulları da malnütrisyonu ağırlaştırıyor olabilir.

Anahtar kelimeler: Çocukluk çağı, malnütrisyon, z skoru.

Kaçar D, Polat E, Zorlu P. Beş yaş altında malnütrisyon tanısı ile üçüncü basamak bir merkezde yatırılarak izlenen olguların değerlendirilmesi. Pam Tıp Derg 2022;15:433-440.

\begin{abstract}
Purpose: Malnutrition which is presented as a disruption of normal growth due to inadequate nutrient intake, is mostly seen in early childhood. Severe cases with complications should be treated at hospital. The aim of this study is to evaluate the follow-up of inpatient children with malnutrition diagnosis under five years old.

Materials and methods: Children with corrected ages 1 to 60 months and hospitalized at a tertiary care training and research hospital with malnutrition diagnosis between May 2006 and May 2011 were evaluated retrospectively. Nutrition status of the patients were determined by the $z$ scores which were calculated according to 2006 World Health Organization growth standards.

Results: All of the included 97 patients' weight for age z scores were below -3 and they were all severely underweight. Low birth weight $(23.7 \%$ in the group, $10-11 \%$ in the community) and parental consanguinity (48.7\% in the group, $21-22 \%$ in the community) ratios in the group were higher than the community. Prior hospital stay $(54.9 \%)$, prematurity $(15.5 \%)$, chronic diseases $(18.5 \%)$ frequencies were also high and an important percentage of patients $(15.4 \%)$ received additional diagnosis during study period. Mortality rate was $5.1 \%$ and occurred in patients under 6 months age who were more severe chronically malnourished.

Conclusion: Malnourished children under five years managed in hospital frequently have underlying medical complexities. Besides, their social and economic circumstances may aggravate malnutrition.
\end{abstract}

Key words: Childhood, malnutrition, z score.

Kacar D, Polat E, Zorlu P. Evaluation of cases under five years old hospitalized with malnutrition in a tertiary care center. Pam Med J 2022;15:433-440.

Dilek Kaçar, Uzm. Dr. Sağlık Bilimleri Üniversitesi, Ankara Şehir Hastanesi, Çocuk Hematoloji Onkoloji Kliniği, Ankara, Türkiye, e-posta: dilekbank@yahoo.com (https://orcid.org/0000-0003-0825-8316) (Sorumlu Yazar)

Emine Polat, Uzm. Dr. Sağlık Bilimleri Üniversitesi, Dr. Sami Ulus Kadın Doğum ve Çocuk Sağlığı ve Hastalıkları Eğitim Araştırma Hastanesi, Çocuk Sağlığı ve Hastalıkları Kliniği, Ankara, Türkiye, e-posta: emine227@yahoo.com (https://orcid.org/0000-0003-3034-5037)

Pelin Zorlu, Uzm. Dr. Sağlık Bilimleri Üniversitesi, Dr. Sami Ulus Kadın Doğum ve Çocuk Sağlığı ve Hastalıkları Eğitim Araştırma Hastanesi, Çocuk Sağlığı ve Hastalıkları Kliniği, Ankara, Türkiye e-posta: pelin.zorlu@gmail.com (https://orcid.org/0000-0003-1572-1823) 


\section{Giriş}

Çocukluk çağında malnütrisyon; intiyaç duyulan ve alınan besin arasındaki dengesizlik sonucunda protein, enerji, eser element eksikliklerinin gelişmesi ve bu sebeple büyüme ve gelişmenin olumsuz etkilenmesi olarak tanımlanır [1]. Sosyoekonomik sebeplerle gıdaya ulaşamama veya anoreksi gibi beslenme tutumundaki bozuklukların sonucu olabileceği gibi, kronik hastalıklar zemininde ve hastane yatışları sırasında da malnütrisyon gelişebilir [13].

Malnütrisyon tanısı, beslenme durumu ve malnütrisyon için hazırlayıcı faktörler göz önüne alınarak antropometrik ölçümlerle koyulur [4]. Dünya Sağlık Örgütü (DSÖ) Nisan 2006'da doğumdan 60 aya kadar olan yaş grubunun büyüme ve gelişmesini değerlendirmek için çok merkezli uluslararası bir çalışmanın verileri ile oluşturulan DSÖ çocuk büyüme standartlarını yayınlamıştır. Antropometrik ölçümlerin, persentil eğrilerine göre daha kesin sonuçlar veren z skorları (standart sapma skorları) ile ifade edilmesini önermiştir [5]. Bu skorlardan boya göre ağırlık $(B / A)$ z skoru, ölçüm tarihinin hemen öncesindeki beslenme durumunu gösterirken; yaşa göre boy (Y/B) z skoru uzun süreli beslenmeyi yansıtır. Yaşa göre ağılık $(Y / A) z$ skoru ise $B / A$ ve $Y / B$ indekslerinin birleşik bir göstergesidir ve hem akut hem de kronik yetersiz beslenmeden etkilenir [6].

Malnütrisyon özellikle ağır olduğunda ölüm riski taşımaktadır. Düşük ve orta gelirli ülkelerde 2011 'de çocuk ölümlerinin \%45'i malnütrisyonla ilişkilendirilmiştir [7]. Malnütrisyon tedavisinin amacı; kısa dönemde mortaliyeti önlemek, sürdürülebilir şekilde beslenmeyi iyileştirerek yaşamı tehdit eden enfeksiyonların önüne geçmek ve nörokognitif gelişimi desteklemektir. Ağır malnütrisyonu olan hastalar iştahsızlık ve alt solunum yolu enfeksiyonu, solukluk, yüksek ateş, dehidratasyon ve uykuya eğilim gibi komplikasyonlar varlığında hastanede tedavi edilmelidir [8].

Bu çalışmada, üçüncü basamak bir hastanede malnütrisyon tanısı ile yatırılarak izlenen 5 yaş altındaki hastaların epidemiyolojik verilerinin değerlendirilmesi amaçlanmıştır.

\section{Gereç ve yöntem}

Çalışmaya Dr. Sami Ulus Kadın Doğum, Çocuk Sağlığı ve Hastalıkları Eğitim Araştırma Hastanesi'nde Çocuk Sağlığı ve Hastalıkları Kliniği'nde Mayıs 2006-Mayıs 2011 tarihleri arasında yatırılarak takip ve tedavi edilen, yatış tanısı ya da yatış tanılarından biri protein enerji malnütrisyonu olan, düzeltilmiş yaşları 1-60 ay arasında değişen hastalar alındı. Çalışma, birinci yazarın Çocuk Sağlığı ve Hastalıkları uzmanlık alanında yaptığı retrospektif tez çalışması olduğu için etik kurul onayı alınmamıştır.

Hastaların dosyaları incelenerek; doğum bilgileri, daha önce hastanede yatış ve kronik hastalık gibi özgeçmiş bilgileri, anne baba akrabalığı ve kardeş ölümü gibi soy geçmiş bilgileri, evdeki beslenme öyküleri, başvuru sırasındaki ve taburculuktaki boy ve kilo bilgileri, hastanedeki beslenme, tedavi ve klinik seyirleri, taburculuk sonrası izlemleri kaydedildi. Üç yaş altındaki prematüre olgular için (doğum haftası 37 haftadan az olanlar) 40 haftaya göre düzeltilmiş yaşları hesaplandı. Hastaların beslenme durumlarını belirlemek için kullanılan B/A, Y/B ve Y/A z skorları 2006 DSÖ büyüme standartlarını temel alan WHO Anthro programı kullanılarak hesaplandı. Z skorlarından en az 1'i -2'nin altında olmayan, doğum haftası ve doğum ağırlığı bilgilerine ulaşılamayan hastalar çalışmaya alınmadı. Dünya Sağlık Örgütü önerilerine göre; B/A z skoru -2 ile -3 arasında olan çocuklar zayıf (wasted), -3'ün altında olanlar çok zayıf; Y/B z skoru -2 ile -3 arasında olan çocuklar kısa (stunted), -3'ün altında olanlar çok kısa, Y/A z skoru -2 ile -3 arasında olanlar düşük kilolu (underweight), -3'ün altında olanlar çok düşük kilolu olarak kabul edildiler [6, 9].

\section{İstatistiksel yöntem}

Verilerin tanımlayıcı istatistiklerinde ortalama, standart sapma, medyan, en düşük, en yüksek ve oran değerleri kullanıldı. Değişkenlerin dağılımı Kolmogorov-Smirnov test ile ölçüldü. Nicel bağımsız verilerin analizinde ANOVA (Tukey test), bağımsız örneklem t test, KruskalWallis, Mann-Whitney U test kullanıldı. Bağımlı nicel verilerin analizinde eşleştirilmiş örneklem $\mathrm{t}$ test, Wilcoxon testi kullanıldı. Nitel bağımsız verilerin analizinde ki-kare test, ki-kare test koşulları sağlanmadığında Fisher test kullanıldı. Veri analizleri Statistical Package for the Social 
Sciences (SPSS) 20.0 for Windows paket programı ile yapıldı.

\section{Bulgular}

Çalışmaya hastaneye yatış tanısı ya da yatış tanılarından biri protein enerji malnütrisyonu olan 97 hasta alındı. Hastaların tamamı Türkiye Cumhuriyeti vatandaşı idi ve Türkiye'de yaşamaktaydılar. Hastaların \%50,5'i erkek $(n=49), \% 49,5^{\prime} i(n=48)$ kızdı. Ortalama tanı yaşı $7,9 \pm 8,2$ aydı (1-50,5; medyan 4,5). Olguların $\% 56,7$ 'si $(n=55) \quad 1-6$ ay arasında, \%40,2'si $(n=39) 6-24$ ay arasında, \%3,1'i $(n=3) 24$ ay üzerinde tanı almıştı. $Z$ skorlarının ortalamaları bu 3 yaş grubu için ayrı ayrı hesaplandı (Tablo 1). Her 3 grupta Y/A z skoru ortalamaları hastaların çok düşük kilolu olduğunu gösterecek şekilde -3'ün altında iken, 6-24 ay arası grubun aynı zamanda çok kısa ve çok zayıf olduğunu işaret edecek şekilde $\mathrm{Y} / \mathrm{B}$ ve B/A z skoru ortalamaları da -3'ün altında saptandı. Bununla birlikte yaş gruplarına göre ortalama Y/A, Y/B ve B/A z skorları arasında anlamlı farklılık bulunmadı $(p=0,362, p=0,552, p=0,141)$.

Hastaların \%15,5'inin $(n=15)$ preterm doğum öyküsü varken, \%23,7'si $(n=23)$ düşük doğum ağırlığına (DDA) (doğum ağırlığı <2500 g ) sahipti. Hastaların \%85,6'sı $(n=83)$ takipli gebelik

Tablo 1. Yaş gruplarına göre ortalama z skorları ve malnütrisyon sınıflaması

\begin{tabular}{lllll}
\hline & $1-6$ ay $(n=55)$ & 6-24 ay $(n=39)$ & $24-60$ ay $(n=3)$ & $p$ değeri \\
\hline Y/A z & $-4,10 \pm 1,12$ & $-4,09 \pm 1,21$ & $-3,13 \pm 0,91$ & 0,362 \\
skoru & çok düşük kilolu & $\begin{array}{l}\text { çok düşük kilolu } \\
\text { çok düşük kilolu }\end{array}$ & \\
Y/B z & $-2,85 \pm 1,63$ & $-3,10 \pm 1,93$ & $-3,81 \pm 0,91$ & 0,552 \\
skoru & kısa & çok kısa & $-1,29 \pm 1,55$ & \\
B/A z & $-2,92 \pm 1,66$ & $-3,22 \pm 1,67$ & normal & 0,141 \\
skoru & zayıf & çok zayıf & \\
\hline
\end{tabular}

Y/A, yaşa göre ağırlık; Y/B, yaşa göre boy; B/A, boya göre ağırlık

sonucunda dünyaya gelmişken, doğumların $\% 97,9^{\prime} u \quad(n=95)$ hastanede gerçekleşmişti. Hastaların \%48,5'inde $(n=47)$ anne baba arasında akrabalık öyküsü vardı. Ortalama anne yaşı $27,4 \pm 5,7$ idi (19-44). Vakaların yaşayan kardeş sayılarının ortalaması $1,6 \pm 1,6$ idi (0-9). Hastaların \%9,3'ünün $(n=9)$ kardeş ölüm öyküsü vardı.

Hastaların \%54,6'sı (n=53) daha önce hastanede yatmıştı. Hastaneye yatışların $\% 45,2$ 'si $\quad(n=24)$ yenidoğan problemleri, \%43,3'ü $(n=23)$ enfeksiyonlar, \%11,3'ü $(n=6)$ malnütrisyon sebebi ile olmuştu. Daha önce hastanede yatış durumlarına göre hastaların z skoru ortalamaları Tablo 2'de gösterilmiştir. Hastanede yatmış olguların $Y / A, Y / B$ ve $B / A$ z skoru ortalamaları hastanede yatmamış olanlardan düşüktü $(p=0,000, \quad p=0,035$, $p=0,019$ ).

Olguların \%18,5'inin $(n=18)$ daha önceden tanı koyulmuş kronik hastalıkları vardı (4 olguda konjenital kalp hastalığı, 3 olguda tekrarlayan

Tablo 2. Hastanede yatış öykülerine göre ortalama z skorları

\begin{tabular}{llll}
\hline & \multicolumn{2}{c}{ Öyküde hastane yatışı } & $p$ değeri \\
& $\operatorname{Var}(\mathbf{n}=53)$ & Yok $(\mathbf{n}=\mathbf{4 4})$ & \\
\hline Y/A z skoru & $-4,42 \pm 1,16$ & $-3,59 \pm 0,91$ & 0,000 \\
Y/B z skoru & $-3,20 \pm 1,69$ & $-2,57 \pm 1,48$ & 0,035 \\
B/A z skoru & $-3,36 \pm 1,83$ & $-2,56 \pm 1,37$ & 0,019 \\
\hline
\end{tabular}

Y/A, yaşa göre ağırlık; $Y / B$, yaşa göre boy; B/A, boya göre ağırlık 
akciğer enfeksiyonu, 3 olguda sindirim sistemi bozuklukları, 3 olguda nörolojik bozukluklar, 3 olguda konjenital anomaliler, 1 olguda pulmoner hipertansiyon, 1 olguda hipotiroidi). Hastaların $\% 15,4$ 'üne $(n=15)$ ise malnütrisyon sebebi ile yatışları sırasında ek hastalık tanıları koyulmuştu (Tablo 3).

Hastaların \%97,9'unun ( $n=95)$ beslenme öyküsüne ulaşılabildi. Anne sütü alım oranı
$\% 91,5$ ( $n=87$ ) iken, formül mama alım oranı $\% 65,2$ ( $n=62$ ) idi. Yaşı 6 ay üzerinde olan hastaların $(n=40)$ yalnızca anne sütü alım süresi ortalama 3,16 $\pm 2,52$ aydı $(0-11)$ ve \%25'i $(n=10)$ ek gıdaya başlamamıştı. Yaşı 6 ay altında olan hastaların $(n=55)$ ise \%10,6'sı $(n=6)$ ek gıdaya başlamıştı.

Beslenme bilgilerine ulaşılabilen 95 hastanın tamamı hastanede yatışlarının ortalama

Tablo 3. Malnütre hastalarda saptanan diğer hastalıklar

\begin{tabular}{ll}
\hline Hastalık & Hasta sayısı (n) \\
\hline Kistik fibrozis & 2 \\
Bartter sendromu & 2 \\
Gastroözefageal reflü & 2 \\
Laktoz intoleransı & 2 \\
Çölyak hastalığı & 1 \\
Kronik karaciğer hastalığı & 1 \\
Hipoaldesteronizm & 1 \\
Velofarengeal yetmezlik & 1 \\
Spinal muskuler atrofi & 1 \\
Rikets & 1 \\
Joubert sendromu & 1 \\
\hline
\end{tabular}

$1,37 \pm 1,21$. gününde $(0-10)$ oral yolla beslenmeye geçebilmişti. Aynı hasta birden fazla besin çeşidi ile beslenebilmekle birlikte, hastanede en sık verilen besinler; formül mama (\%82,1 hasta, $\mathrm{n}=78)$, anne sütü $(\% 35,7$ hasta, $n=34)$ ve sofra yemekleri (\%27,3 hasta, $n=26)$ idi. Hiçbir hastada refeeding sendromu gelişmemişti.

Hastaların \%44,3'üne $\quad(n=43)$ yatışları sırasında; dehidratasyon ve elektrolit dengesizlikleri $(n=20)$, başta pnömoni olmak üzere enfeksiyonlar $(n=20)$ ve oral alım intoleransı $(n=3)$ sebebi ile parenteral SIVI verilmişti. Parenteral sıvı intiyacı olan ve olmayan hastaların z skoru ortalamaları Tablo 4'te gösterilmiştir. Parenteral SIVı alanların Y/A ve $B / A$ z skoru ortalamaları almayanlara göre düşükken $(p=0,005, p=0,000), Y / B \quad z$ skorları arasında anlamlı fark yoktu $(p=0,984)$.
Hastaların \%57,7'sine $\quad(n=56)$ yatışları sırasında antibiyotik verilmişti. Antibiyotik verilme endikasyonları; pnömoni (\%21,6 $\mathrm{n}=21)$, idrar yolu enfeksiyonu (\%13,4 $n=13)$, profilaksi $(\% 8,2$ $n=8)$, nozokomiyal enfeksiyonlar $(\% 6,2 \mathrm{n}=6)$, sepsis $(\% 5,2 n=5)$, parazitik enfeksiyonlar $(\% 2,1$ $n=2)$ ve otitis media $(\% 1 \mathrm{n}=1)$ idi.

Hastaların $\% 74,2$ 'sine $(n=72)$ bir ya da daha fazla eser element desteği verilmişti. En sık (\%64,9 hasta, $n=63$ ) hastanemizde "malnütrisyon protokolü" olarak bilinen eser element protokolü verilmişti. Malnütrisyon protokolü; 1 yaş altında 100000 IU, 1 yaş üzerinde 200000 IU ağızdan tek doz A vitamini, 2 hafta boyunca ağızdan $\mathrm{MgSO}_{4}$ $60 \mathrm{mg} / \mathrm{kg} / \mathrm{gün}$ (en fazla $300 \mathrm{mg}$ ), $\mathrm{ZnSO}_{4} 50 \mathrm{mg} /$ gün, $\mathrm{CuSO}_{4}, 0,2 \mathrm{mg} / \mathrm{kg} / \mathrm{gün}$ ve $\mathrm{K}^{+} 4 \mathrm{mMol} / \mathrm{kg} /$ gün; 2 ay boyunca ağızdan folik asit $100 \mu g / g u ̈ n$ ve günlük ihtiyacın 1-2 katı kadar multivitamin

Tablo 4. Parenteral sıvı ihtiyacına göre ortalama z skorları

\begin{tabular}{llll}
\hline & Parenteral sıvı alanlar $(\mathrm{n}=43)$ & Parenteral sıvı almayanlar $(\mathrm{n}=54)$ & $p$ değeri \\
\hline Y/A z skoru & $-4,43 \pm 1,27$ & $-3,78 \pm 0,96$ & 0,005 \\
Y/B z skoru & $-2,98 \pm 2,03$ & $-2,97 \pm 1,48$ & 0,984 \\
B/A z skoru & $-3,65 \pm 1,18$ & $-2,48 \pm 1,83$ & 0,000 \\
\hline
\end{tabular}

Y/A, yaşa göre ağırlık; Y/B, yaşa göre boy; B/A, boya göre ağılık 
kompleksi ve tedavinin 2 . haftasından sonra başlanacak ağızdan 4-6 $\mathrm{mg} / \mathrm{kg} / \mathrm{gün} \quad \mathrm{Fe}^{++}$ içermekteydi. Hastaların \%15,4'üne $(n=15)+2$ değerlikli demir, \%6,1'ine $(n=6)$ D vitamini ve $\% 2$ 'sine $(n=2)$ B12 vitamini verilmişti.

Hastaların \%69,1'inde $\quad(n=67)$ ağırlık artışı gözlenmişti. Kronik hastalığı olan ya da hastanede tanı alan hastaların $(n=35)$ $\% 65,7$ 'sinde, kronik hastalığı olmayan ve hastanede de tanı almayan hastaların $(n=62)$ \%70,9'unda ağırlık artışı saptanmıştı. İki grup arasında ağırlık artışı açısından anlamlı fark bulunmamıştı $(p=0,258)$.

Hastaların \%5,1'i $\quad(n=5) \quad$ hastanede kaybedilmişti. Ölen hastaların yaş ortalaması $3,50 \pm 1,11$ aydı $(2,25-5,25)$. Ölen hastalardan birinde olan yarık damak-dudak dışında tanı koyulmuş kronik hastalıkları yoktu. Tümünün anne babası arasında akrabalık varken, üçünün kardeş ölüm öyküsü vardı. Kaybedilen ve hayatta hastaların z skoru ortalamaları Tablo 5'te gösterilmiştir. Ölen hastaların Y/A ve Y/B z skorları hayatta kalan hastalara göre düşükken, B/A z skorları arasında anlamlı fark yoktu $(p=0,013, p=0,002, p=0,623)$.

Taburcu olan 92 hastanın ortalama hastanede yatış süresi $13,73 \pm 9,08$ gündü (348). Taburcu olan hastaların \%39,1'i $(n=36)$ hastanemizde takiplerine devam etti. Takiplerine devam eden hastalardan biri izlemde çölyak hastalığı, biri kistik fibrozis tanısı aldı (\%2, n=2). Hastalardan beşinin enfeksiyon sebebi ile tekrar hastaneye yatırılması gerekirken, dört hastanın ilerleyen yaşlarda boy kısalığı sebebi ile tetkik edildiği görüldü.

Tablo 5. Hayatta kalan ve ölen hastaların başvuru sırasındaki ortalama z skorları

\begin{tabular}{llll}
\hline & $\begin{array}{l}\text { Ölenler } \\
(n=5)\end{array}$ & $\begin{array}{l}\text { Hayatta kalanlar } \\
(n=54)\end{array}$ & $p$ değeri \\
\hline Y/A z skoru & $-5,30 \pm 1,49$ & $-4,00 \pm 1,10$ & 0,013 \\
Y/B z skoru & $-5,29 \pm 2,47$ & $-2,85 \pm 1,61$ & 0,002 \\
B/A z skoru & $-2,58 \pm 3,49$ & $-3,01 \pm 1,59$ & 0,623 \\
\hline
\end{tabular}

Y/A, yaşa göre ağırık; Y/B, yaşa göre boy; B/A, boya göre ağırlık

\section{Tartışma}

Malnütrisyonun ağırlıklı olarak düşük ve orta gelirli ülkelerde yaşayan 5 yaş altındaki çocuklarda görüldüğü bilinmektedir [8]. Ancak son zamanlarda gelişmiş ülkelerde yaşayan çocuklarda da, sıklıkla altta yatan hastalıklar zemininde malnütrisyon geliştiği gözlenmiştir [10]. Malnütrisyonun tanımlanmasında güncel yaklaşım; süresinin, ağırlığının, davranışsal/ çevresel hangi koşullar altında geliştiğinin ve hangi ölçümlerle tanındığının belirtilmesidir [4].

American Society for Parenteral and Enteral Nutrition (ASPEN) 2 yaş altındaki çocuklarda beslenmenin değerlendirilmesinde DSÖ büyüme standartlarının kullanılmasını önermektedir [1]. Bu çalışmada da kullanılan 2006 DSÖ büyüme standartları, dünyanın her yerinde sağlıklı ortamlarda büyüyen ve beslenme tavsiyelerine uyan çocukların benzer büyüme modelleri sergilediklerini göstermiştir [5]. Tutar ve ark. [11] 60 ay altında 100 Türk çocuğunun Y/A ve Y/B z skorlarını 1978'te raporlanan ulusal Neyzi standartlarına ve 2006 DSÖ standartlarına göre ayrı ayrı hesaplayıp sonuçları karşılaştırdıkla- rında DSÖ grubunda her iki z skorunu çok daha düşük bulmuşlardır $(p<0,001)$. Başka bir çalışmada ise National Center for Health Statistics (NCHS) ile karşılaştıııldığında DSÖ standartları ile 8 kat fazla çocuğun ağır malnütrisyon tanısı aldığı ancak iyileşmenin daha kısa sürede ve daha yüksek oranda olduğu; ölüm, hastaneye yatış ve takipsizlik oranlarının düştüğü bildirilmiştir [12].

Yetersiz beslenme için en riskli dönem konsepsiyondan 24 aya kadar olan hayatın ilk 1000 günü olmakla birlikte tamamlayıcı beslenmenin öne çıktığı 6-18 ay arasında malnütrisyon insidansının belirgin olarak arttığı bildirilmektedir [13, 14]. Bu çalışmaya alınan vakaların \%96,9'unun yaşı 24 ay altındaydı. Her 3 yaş grubundaki (1-6 ay,6-24 ay, 24-60 ay) çocukların uzun süredir yetersiz beslendiğini gösterecek şekilde Y/A z skoru ortalamaları -3'ün altındaydı. Ancak en ağır etkilenen grup 6-24 ay arasındaki çocuklardı. Bu grupta hem uzun dönemde yetersiz beslenmeyi işaret eden $Y / B$, hem de ölçüm tarihinden hemen öncesini yansıtan B/A z skorları -3'ün altında bulundu. 
Yaşı 24 ay üzerinde olan çocuklar ise kronik malnütrisyonun en ağır olduğu grup olmakla birlikte (Y/B z skoru $-3,81 \pm 0,91$, çok kısa) akut malnütrisyonları düzelme eğilimindeydi $(B / A z$ skoru $-1,29 \pm 1,55$, normal).

Çalışmaya alınan çocukların \%48,5'inin anne babaları arasında akrabalık vardı. Bu oran Türkiye Aile Yapısı Araştırması 2006 ve 2011 'de bildirilen $\% 22$ ve $\% 21$ 'lik akraba evliliği oranlarının 2 katından fazla idi [15, 16]. Doğum öncesi takipsizlik oranı çalışma grubunda \%14,4 olup, Türkiye Nüfus ve Sağlık Araştırması (TNSA) 2008 ve TNSA 2013'te bildirilen $\% 7,8$ ve $\% 2,7$ 'den çok daha yüksekti $[6,17]$. Hastaların $\% 15,5$ 'inin preterm doğum öyküsü varken, DDA \%23,7'lik oranla TNSA 2008 ve TNSA 2013'te bildirilen \%10-11 sıklıktan yüksekti [6, 17]. Tam olarak ölüm yaşları bilinmemekle birlikte hastaların \%9,3'ünün çocukluk çağında ölen kardeşleri vardı. TNSA 2008 ve TNSA 2013'te 5 yaş altı çocuk ölüm hızları 1000 'de 24 ve 15 olarak bildirilmiştir [6, 17]. Gebelikten önceki ve gebelik sırasındaki beslenme yetersizliği, doğum komplikasyonları ve DDA ile sonuçlanabilir. $\mathrm{Bu}$ bebeklerin çocukluk çağında ölüm riskleri artmış olduğu gibi; hayatta kalırlarsa düşük kilolu ve/veya bodur olabilirler. Erişkinliklerinde dahi fiziksel ve mental kapasiteleri kısıtlı olabilir ve bu kısıtlılıklar malnütrisyonun sonraki nesile aktarılmasına yol açabilir [18]. Ülkemizde sosyoekomik seviye ve eğitim düzeyi düştükçe akraba evliliği oranının arttığı bilinmektedir $[15,16]$. Çalışmamızda direkt olarak değerlendirilmemiş olsa da yüksek oranda olan akraba evliliği ve DDA sıkığı ailelerin sosyoekonomik seviyelerinin ve eğitim düzeylerinin düşük olduğunu, hatta ebeveynlerin de malnütrisyondan etkilenmiş olabileceğini düşündürmektedir.

Çalışmaya alınan olguların \%54,6'sının yenidoğan problemleri ve enfeksiyonlar başta olmak üzere çeşitli sebeplerle hastaneye yatış öyküsü vardı. Bu çocukların her $3 \mathrm{z}$ skoru, hastanede yatmamış olanlara göre düşüktü. Malnütrisyon gelişimine hastanede yatış gerektirecek durumlar ve enfeksiyonlar zemin hazırlamış olabileceği gibi bu çocuklar hastane yatışları sırasında intiyaç duyulan besinlerin sağlanamaması sebebi ile hastane kaynaklı malnütrisyondan da etkilenmiş olabilirler [1, 3].

Kronik hastalığı olan çocuklar; artmış kalori intiyaçları, malabsorbisyon, beslenme intoleransı, sıVı kısıtlanması sebebi ile malnütrisyon için risk altındadırlar [2]. Olguların \%18,5'inin hastaneye yatarken bilinen kronik rahatsızlıkları vardı. Hastaların $\% 15,4$ 'üne yatışları sırasında, $\% 2$ hastaya ise taburculuk sonrası dönemde ek hastalık tanısı koyuldu. Kronik rahatsızlıklar; kalp, akciğer, sindirim sistemi hastalıkları yanında nörolojik bozukluklardan konjenital anomalilere kadar geniş bir yelpazede dağılmaktaydı. Rutin olarak tarama yapılmamış olmasına rağmen en sık kistik fibrozis (3 hasta) ve çölyak hastalığı (2 hasta) tanıları koyulmuştu. Kistik fibrozisli hastaların; pankreatik yetmezlik, artmış bazal enerji intiyacı ve tekrarlayan akciğer alevlenmeleri sebebi ile malnütrsiyon için risk altında oldukları bilinmektedir [19]. Ağır malnütrisyonlu çocuklarda ise çölyak hastalığı sıklığı \%15 olarak bulunmuştur ve tüm ağır malnütre hastalarda taranması önerilmektedir [20].

United Nations International Children's Emergency Fund (UNICEF) ve DSÖ, malnütrisyon gelişiminde uygun besinler ve beslenme pratikleri hakkında yetersiz bilginin, gıdaya ulaşamamaktan daha önemli rol oynadığına değinmişlerdir [21]. Çalışmamızda, beslenme öyküsüne ulaşılabilen hastaların neredeyse tamamı $(\% 97,9)$ bir süre anne sütü almış olmakla birlikte formül mama kullanım oranı oldukça yüksekti $(\% 65,2)$. Bu veriler, grupta anne sütü ile etkin beslenmenin sürdürülemediğini göstermektedir. Yaşı 6 ay üzerinde olan hastaların \%25'ine ek gıda verilmemiş olması ve yaşı 6 ay altında olanların ise \%10,6'sının ek gıdaya başlamış olması, grupta genel olarak tamamlayıcı beslenme pratiklerinin de yanlış uygulandığını düşündürmektedir.

Malnütrisyon tedavisinde, DSÖ'nün önerdiği süt bazlı $F 75$ (75 kkal/100mL) ve F100 (100 $\mathrm{kkal} / 100 \mathrm{~mL}$ ) mamalar yerine ulaşılabilen ülkelerde formül mama verilebileceği, eğer anne sütü varsa ilk tercih edilecek gıdanın anne sütü olması gerektiği bildirilmiştir [14]. Bizim çalışmamızda bu önerilere uygun olarak aynı hastaya birden fazla besin verilebilmekle birlikte en fazla verilen besinler formül mama, anne sütü ve sofra yemekleri olarak saptanmıştır. Çalışmamıza alınan hastaların \%64,9'una yatışları sırasında hastanemizde "malnütrisyon protokolü” olarak bilinen eser element protokolü 
verilmişti. Bu protokolün içerdiği eser elementler ve dozları literatürde önerilen protokollerle uyumluydu [9, 14]. Hastanemizde verilen protokol literatürden farklı olarak fosfor desteğini içermese de hastalarımızda refeeding sendromu gözlenmemişti. Parenteral sıvı intiyacı olan $\% 44,3$ hastada ise akut malnütrisyonun sıVı intiyacı olmayanlara göre daha ağır olduğunu gösterecek şekilde Y/A ve B/A z skorları daha düşüktü.

Malnütrisyonda; barsak bariyer fonksiyonu ve koruyucu maddelerin ekzokrin salınımı bozulmuştur. Lenfatik dokular atrofiktir ve plazma kompleman seviyeleri düşüktür. Enfeksiyonlar ve enfeksiyon ilişkili mortalite artmıştır [22]. Bu sebeple DSÖ malnütrisyon tanısı ile hastaneye yatırılan her çocuğa profilaktik antibiyotik verilmesini önermektedir [9]. Çalışmamızdaki hastaların \%57,7'sine antibiyotik tedavisi verilmişken profilaksi bunun yalnızca $\% 8,2^{\prime}$ 'lik kısmını, nozokomiyal enfeksiyonlar \%6,2'sini, sepsis ise \%5,2'sini oluşturmaktaydı. En sık antibiyotik endikasyonu pnömoniydi $(\% 21,6)$. Çocukluk çağında malnütrisyon ve pnömoni en önemli iki mortalite sebebidir ve ağır malnütrisyonu olan olgularda pnömoniye bağlı mortalite riskinin 2,9-121,2 kat arttığı, pnömoni etkenlerinin farklı olduğu ve klinik bulguların radyografik pnömoniyi değerlendirmede çok duyarlı olmadığı bildirilmiştir [23]. Çalışmamızda ikinci en sık antibiyotik endikasyonu idrar yolu enfeksiyonuydu $(\% 13,4)$. Malnütrisyonlu çocuklarda idrar yolu enfeksiyonu sıklığı \%17 olarak bildirilmiştir ve malnütrisyon varlığında rutin olarak taranması önerilmektedir [24].

Malnütrisyon tedavisi ile kronik hastalığı olan ve olmayan hastaların ağırlık artışları arasında fark bulunmamıştı. Bu durum, kronik hastalıkların malnütrisyon tedavisinde başarıyı etkilemediğini düşündürmektedir.

Çalışma grubundaki hastaların \%5,1'i yaşları henüz 6 ay altında iken kaybedilmişti. Ölen hastaların, hayatta kalan hastalara göre kronik malnütrisyonlarının daha ağır olduğunu gösterecek şekilde Y/A ve Y/B z skorları daha düşüktü. Tanı koyulmuş hastalıkları olmamakla birlikte tümünün anne babası arasında akrabalık vardı ve üçünün kardeş ölüm öyküsü vardı. Bu grupta, malnütrisyona ek olarak henüz tanı koyulamamış kalıtsal hastalıkların mortaliteden sorumlu olabileceği düşünülmüştür.
Çocukluk çağında malnütrisyon; davranışsal, çevresel, sosyoekonomik, hastalık ve hastane ilişkili birçok koşul altında gelişebilir. Üçüncü basamak bir merkezde yapılan çalışmamızda malnütrisyon sebebi ile hastanede yatırılarak izlenen beş yaş altındaki çocukların; prematürite, DDA, yüksek oranda kronik hastalık ve akraba evliliği gibi karışık tıbbi durumlarının olduğunu gördük. Bu grubun aynı zamanda sosyal ve ekonomik faktörlerle ilişkili malnütrisyon riski de taşıyor olabileceklerini düşündük. Sonuç olarak; çocukluk çağında en önemli mortalite sebeplerinden biri olan malnütrisyonun tedavisi, altta yatan durumlar dikkatle irdelenerek aile eğitimi dâhil olmak üzere çok yönlü olmalıdır.

Çıkar ilişkisi: Yazarlar çıkar ilişkisi olmadığını beyan eder.

\section{Kaynaklar}

1. Mehta NM, Corkins MR, Lyman B, et al. Defining pediatric nalnutrition: a paradigm shift toward etiologyrelated definitions. J Parenter Enteral Nutr 2013;37:460481. https://doi.org/10.1177/0148607113479972

2. Nath CL, Goday P. Malnutrition in children with chronic disease. Nutr Clin Pract 2019;34:349-358. https://doi. org/10.1002/ncp.10274

3. Vega MW, Beer S, Juarez M, Srivaths PR. Malnutrition risk in hospitalized children: a descriptive study of malnutrition-related characteristics and development of a pilot pediatric risk-assessment tool. Nutr Clin Pract 2019;34:406-413. https://doi.org/10.1002/ncp.10200

4. Bouma S. Diagnosing pediatric malnutrition: paradigm shifts of etiology-related definitions and appraisal of the indicators. Nutr Clin Pract 2016;32:52-67. https://doi. org/10.1177/0884533616671861

5. WHO Multicentre Growth Reference Study Group. WHO child growth standards based on length/height, weight and age. Acta Paediatr 2006;95:76-85. https:// doi.org/10.1111/j.1651-2227.2006.tb02378.x

6. Hacettepe Üniversitesi Nüfus Etütleri Enstitüsü (2009) Türkiye Nüfus ve Sağlık Araştırması, 2008. Hacettepe Üniversitesi Nüfus Etütleri Enstitüsü, Sağlık Bakanlığı Ana Çocuk Sağlığı ve Aile Planlaması Genel Müdürlüğü, Başbakanlık Devlet Planlama Teşkilatı Müsteşarlığı ve TÜBITAK, Ankara, Türkiye. Erişim adresi: https://sbu.saglik.gov.tr/Ekutuphane/kitaplar/ TNSA-2008_tr.pdf. Erişim tarihi 03 Ekim 2020

7. Black RE, Victora CG, Walker SP, et al. Maternal and child undernutrition and overweight in low-income and middle-income countries. Lancet 2013;382:427-451. https://doi.org/10.1016/S0140-6736(13)60937-X

8. Bhutta ZA, Berkley JA, Bandsma RHJ, Kerac M, Trehan I, Briend A. Severe childhood malnutrition. Nat Rev Dis Primers 2017;3:17067. https://doi.org/10.1038/ nrdp.2017.67 
9. World Health Organization. Management of severe malnutrition: a manual for physicians and other senior health workers. Geneva: WHO, 1999. Available at: https://apps.who.int/iris/handle/10665/41999. Accessed October 03, 2020

10. Corkins MR. Why is diagnosing pediatric malnutrition important? Nutr Clin Pract 2017;32:15-18. https://doi. org/10.1177/0884533616678767

11. Tutar E, Boran P, Öktem S, Tokuç G, Çalışkan B. Malnutrition in hospitalized pediatric patients: A comparison of the national Turkish and World Health Organization (WHO) child growth standards. Marmara Medical Journal 2012;25:128-132. https://doi. org/10.5472/MMJ.2012.02242.1

12. Isanaka S, Villamor E, Shepherd S, Grais RF. Assessing the impact of the introduction of the World Health Organization growth standards and weight-forheight z-score criterion on the response to treatment of severe acute malnutrition in children: secondary data analysis. Pediatrics 2009;123;54-59. https://doi. org/10.1542/peds.2008-1375

13. World Bank. Repositioning nutrition as central to development: A strategy for large scale action. 1st ed. Washington, DC. (C) World Bank, 2006. Available at: http://hdl.handle.net/10986/7409. Accessed October 05, 2020

14. Ashwoth A. Nutrition, food security and health. In: Kliegman RM, St Geme III JW, Blum NJ, Shah SS, Tasker RC, Wilson KM, Behrman RE eds. Nelson textbook of pediatrics. 21th ed. Philadelphia: Elsevier Inc, 2019;331-342.

15. T.C. Aile ve Sosyal Politikalar Bakanlığı Aile ve Toplum Hizmetleri Genel Müdürlüğü. Türkiye Aile Yapısı Araştırması 2006. 2. Baskı. Ankara.2014. Erişim adresi: https://ailevecalisma.gov.tr/uploads/athgm/ uploads/pages/indirilebilir-yayinlar/60-aileyapisiarastirmasi-2006.pdf. Erişim tarihi 18 Nisan 2021

16. T.C. Aile ve Sosyal Politikalar Bakanlığı Aile ve Toplum Hizmetleri Genel Müdürlüğü. Türkiye Aile Yapısı Araştırması 2011. 2. Baskı. Ankara.2014. Erişim adresi: https://ailevecalisma.gov.tr/uploads/athgm/ uploads/pages/indirilebilir-yayinlar/65-aileyapisiarastirmasi-2011.pdf. Erişim tarihi 18 Nisan 2021

17. Hacettepe Üniversitesi Nüfus Etütleri Enstitüsü (2014), "2013 Türkiye Nüfus ve Sağlık Araştırması". Hacettepe Üniversitesi Nüfus Etütleri Enstitüsü, T.C. Kalkınma Bakanlığı ve TÜBITAK, Ankara, Türkiye. Erişim adresi: http://www.hips.hacettepe.edu.tr/tnsa2013/rapor/ TNSA_2013_ana_rapor.pdf. Erişim tarihi 03 Ekim 2020

18. Administrative Committee on Coordination and Sub Committee on Nutrition (ACC/SCN) and International Food Policy Research Institute (IFPRI) (2000). 'Fourth Report on The World Nutrition Situation', United Nations, Switzerland. Available at: https://www.ifpri. org/publication/4th-report-world-nutrition-situation. Accessed 05 Ekim 2020
19. Dhochak N, Jat KR, Sankar J, Lodha R, Kabra SK. Predictors of malnutrition in children with cystic fibrosis. Indian Pediatr 2019;56:825-830.

20. Beniwal N, Ameta G, Chahar CK. Celiac disease in children with severe acute malnutrition (SAM): a hospital based study. Indian J Pediatr 2017;84:339343. https://doi.org/10.1007/s12098-017-2300-x

21. World Health Organization: Global strategy for infant and young child feeding. Geneva: World Health Organization; 2003. Available at: https://www.who.int/ publications/i/item/9241562218. Accessed May 11, 2021

22. Rytter MJH, Kolte L, Briend A, Friis $H$, Christensen VB. The immune system in children with malnutrition-a systematic review. PLoS One 2014;25;9:105017. https://doi.org/10.1371/journal.pone.0105017

23. Chisti MJ, Tebruegge M, Vincette SL, Graham SM, Duke T. Pneumonia in severely malnourished children in developing countries- mortality risk, aetiology and validity of WHO clinical signs: a systematic review. Tropical Medicine and International Health 2009;14:1173-1189. https://doi.org/10.1111/j.13653156.2009.02364.x

24. Uwaezuoke SN, Ndu IK, Eze IC. The prevalence and risk of urinary tract infection in malnourished children: a systematic review and meta-analysis. BMC Pediatrics 2019;19:261. https://doi.org/10.1186/s12887-019$1628-y$

Etik kurul onayı: $\mathrm{Bu}$ çalışma birinci yazarın çocuk sağlığı ve hastalıkları uzmanlığı tez çalışması olup 2012 yılında yapılmıştır. Retrospektif çalışma olduğu için etik kurul onayı alınmamıştır.

\section{Yazarların makaleye olan katkıları}

D. K. ve E.P. çalışmanın ana fikrini ve hipotezini kurgulamıştır. D.K. ve E.P. teoriyi geliştirmiş, gereç ve yöntem bölümünü düzenlemişlerdir. Sonuçlar kısmındaki verilerin değerlendirmesini D.K ve E.P. yapmıştır. Makalenin tartışma bölümü D.K. tarafından yazılmış E.P. ve P.Z. gözden geçirip gerekli düzeltmeleri yapmış ve onaylamıştır. Ayrıca tüm yazarlar çalışmanın tamamını tartışmış ve son halini onaylamıştır. 